\title{
Respiratory symptoms and diseases among workers in the soft tissue producing industry
}

\author{
T Kraus, A Pfahlberg, O Gefeller, H J Raithel
}

Occup Environ Med 2002;59:830-835

See end of article for authors' affiliations

Correspondence to

Dr T Kraus, Institute and Outpatient Clinic for Occupational Medicine, University Hospital, Aachen University of Technology, Pauwelsstr. 30, D-52074 Aachen, Germany; thomas.kraus@post. rwth-aachen.de

Accepted 14 May 2002

\begin{abstract}
Aims: To correlate the prevalence of respiratory tract symptoms and diseases with dust and fibre exposure in the soft tissue industry in Germany.

Methods: Ambient monitoring was performed for inhalable, respirable dust and fibres in seven soft tissue producing factories. In 441 workers (72 controls, 90 moderate, 279 high exposure) a standardised questionnaire on respiratory symptoms, diseases, occupational history, and smoking habits was used. Crude differences in the prevalence of respiratory symptoms and diseases were assessed. Logistic regression analysis was used to determine the relation between the respiratory symptoms/diseases and the cumulative dust and fibre exposure, respectively, while adjusting for age, gender, smoking habits, and factory. The effects of exposure intensity and duration were differentiated by categorising dust/fibre concentrations and years of exposure separately and setting up logistic regression models. Results: The mean concentrations for inhalable, respirable, and fibrous dusts were $10.3 \mathrm{mg} / \mathrm{m}^{3}$, $0.22 \mathrm{mg} / \mathrm{m}^{3}$, and 415000 fibres $/ \mathrm{m}^{3}$. Adjusted odds ratios (OR) with relation to cumulative dust exposure intensity were significantly raised for blocked nose (18.2), mucosal irritation (6.5), dry nose (8.9), cough (3.5), phlegm (7.5), exercise induced dyspnoea (2.6), hoarseness (1 1.3), and sneezing attacks (7.9) (ORs for highest exposure categories). Cumulative dust or fibre exposure had no significant effects on the prevalence of respiratory diseases. For all symptoms with significantly raised ORs, combined effects of intensity and duration of exposure were found.

Conclusions: Because of the high prevalence of respiratory symptoms a reduction of dust exposures is recommended. Chronic exposure effects could not be found in this study, however, a healthy worker effect has to be considered.
\end{abstract}

C ellulose is an insoluble polysaccharide and the most frequent biopolymer in nature. It is produced from hard and soft woods. The technical product cellulose tissue additionally consists of polyoses and the remains of lignin, and has to undergo cleaning processes. The highest consumption of cellulose, in particular cellulose tissue, is in the fields of paper production and processing as well as in the textile industry.

Because of the wide use of cellulose and cellulose tissue, a high number of workers are exposed to cellulose containing dusts, which contain cellulose fibres according to the WHO definition (length $>5 \mu \mathrm{m}$, diameter $<3 \mu \mathrm{m}$, length/diameter ratio $>3: 1$ ). Hard wood dusts, especially fibre dusts, represent a health hazard in man. Geometric fibre properties and biopersistency are important factors for health risks of fibrous dusts. Animal experiments with hard wood dust cellulose fibres and cellulose fibre products (Isofloc) showed a relatively high biopersistency with a biological half life of the fibre clearance of about 1000 days. Moreover, granulomatous pneumonia and minimal interstitial fibrosis, as well as alveolar cell type hyperplasia were found in rats. ${ }^{1-4}$ In the literature there is limited evidence for an increased prevalence of respiratory symptoms, especially of the upper airways in paper workers. ${ }^{5}$ Some authors have also reported an increased prevalence of lower respiratory tract symptoms. ${ }^{67}$ Thorén et al described an increased risk for asthma and chronic obstructive lung diseases in workers in paper mills. ${ }^{78}$ However, the authors were not able to describe causal relations with certain exposures.

The aim of our study was to describe the prevalence of respiratory tract symptoms and diseases, and to correlate these with detailed information on the corresponding dust exposures in different workshops of the soft tissue industry in Germany.

\section{STUDY GROUP AND METHODS}

The study group was recruited from seven soft tissue producing companies from different parts of Germany. In every company pure cellulose was the basis of the production process. Recycled paper was not a relevant component of the products. Cellulose is first put into pulping machines and a large amount of water is added. The pulp is then put into huge paper machines, where the dehydrating and drying process is performed. The result of this process is the so called mother rolls (huge paper rolls). The converting process then begins, with printing and cutting the product in combiner machines. Finally the soft tissue products are packed. During this production process, high dust concentrations appear, especially at the paper machine and during the converting process.

The study group comprised all persons working in the production unit of the seven companies. It was a random sample of German soft tissue companies. There was no selection by exposure intensity, size of the factories, health complaints among employees, or other factors. Data were collected from 441 persons. According to the employers' information, we interviewed all persons from the different workshops employed during the time period 1996-98. However, we were unable to check the list of all persons employed and to compare it with the list of persons interviewed by ourselves. Table 1 presents characteristics of the study group.

The data concerning dust measurements were gathered from 1991 to 1997. Dust measurements were performed according to the Technical Guidelines for the Detection and Measurement of Hazardous Substances. ${ }^{9}$ The mean sampling time was 1.97 hours (range 0.16-3.8). The cross sectional study with the data collection concerning respiratory symptoms and respiratory diseases took place between 1996 and 1998. Three subgroups were defined a priori within the study group. Group 1 consisted of control persons of each company 
Table 1 Number, age, gender, smoking habits, and duration of exposure of controls, and moderate and high exposed workers

\begin{tabular}{lccc}
\hline & Controls & Moderate exposure & High exposure \\
\hline Number & 72 & 90 & 279 \\
Age, mean (SD) & $43.4(9.6)$ & $41.1(10.1)$ & $40.2(9.7)$ \\
Females (\%) & 36.4 & 5.3 & 23.2 \\
Smokers (\%) & 31.9 & 43.3 & 50.5 \\
Former smokers (\%) & 6.9 & 18.9 & 15.4 \\
Never smokers (\%) & 61.1 & 37.8 & 34.1 \\
Exposure (years), mean (SD) & - & $16.8(9.5)$ & $15.6(8.9)$ \\
\hline
\end{tabular}

from the management departments. Group 2 had moderate exposure (maintenance workers, electricians, mechanics). Group 3 consisted of workers from the production workshops (paper machine, combiner) and were classified as being high exposed. Because of differences in the exposure intensity between the seven companies a cumulative exposure index was generated for describing the individual exposure. The mean of the dust and fibre concentration of each company was multiplied by the individual time of exposure of high exposed persons. In cases of moderate exposure, the mean dust and fibre concentration of each company was divided by four and multiplied by the individual time of exposure. According to the information from technical experts, this attenuation factor is the best representation of the intermittent and lower exposure of those workers. For each participant a cumulative exposure index was available for dusts and for fibres. Because dust measurements for the respirable fraction were not available from each company, no exposure index was calculated for this fraction.

All subjects were interviewed using a standardised questionnaire with detailed information on occupational history, duration of exposure, workshop within the company, technical and personal protection measurements, former occupational exposures, and former respiratory diseases. ${ }^{10}$ Moreover, work related symptoms as mucosal irritation, cough, phlegm, dyspnoea, blocked and dry nasal mucosa, as well as sneezing attacks were documented. Details of smoking habits were requested. All questions were asked by the same physician (HJR).

Statistical analysis was performed in three steps. In the first step, crude differences in the prevalence of respiratory symptoms and diseases for different ordered exposure levels were assessed using the exact Cochran-Armitage trend test. ${ }^{11}$ Here, no adjustments for other variables were made, so that the results are prone to being confounded.

In the second step, we employed logistic regression analysis to determine the relation between the outcome variables of interest and the cumulative dust and fibre exposure, adjusting for important confounders such as age, gender, smoking habits, and factory. Results of the logistic models are reported by giving estimates of the odds ratio (OR) as a measure of the strength of the association, with $95 \%$ confidence intervals (CI) derived by the profile likelihood method. ${ }^{12}$
In the third step, we aimed to differentiate between the effects of exposure intensity and the effects of exposure duration. We therefore categorised dust/fibre concentrations and years of exposure separately, and set up logistic regression models incorporating both variables as ordered exposure factors. Inspection of the changes in the ORs for the categories formed by the combination of the two factors allowed us to assess which of the two factors has a more pronounced influence on outcome risk and where interaction effects might be operating.

Whenever possible we used the data from the control group as the reference level. In some situations, none from the control group showed the respiratory symptom/disease modelled as the outcome of interest. In these cases the group with the lowest exposure served as reference.

All reported p values are two sided; those lower than 0.05 were considered significant. The statistical analyses were performed using the software packages SPSS, version 10, and SAS, version 8.1, respectively.

\section{RESULTS}

\section{Ambient monitoring}

Table 2 presents the results of ambient monitoring of dust and fibre concentrations. The mean concentration for inhalable dusts was $10.3 \mathrm{mg} / \mathrm{m}^{3}$. Maximum concentrations found were $30 \mathrm{mg} / \mathrm{m}^{3}$ inhalable dust during the production process at the machines and $96 \mathrm{mg} / \mathrm{m}^{3}$ during cleaning the machines with pressure air. Measurements of the respirable dust fraction in three of seven companies yielded mean concentrations of 0.22 $\mathrm{mg} / \mathrm{m}^{3}$ with a maximum of $1.02 \mathrm{mg} / \mathrm{m}^{3}$. The mean ratio of respirable to inhalable fraction was $4.5 \%$. The maximum fibre concentration was 1.5 million fibres $/ \mathrm{m}^{3}$. Mean fibre concentration was 415000 fibres $/ \mathrm{m}^{3}$ (table 2). There were considerable differences of cumulative dust and fibre exposure indices between the factories. Factories 1 to 7 had, respectively, mean cumulative dust indices of 149.1, 49.9, 73.8, 90.2, 140.9, 131.4, and 57.6 dustyears $\left(\mathrm{mg} / \mathrm{m}^{3} \times\right.$ years $)$ and cumulative fibre indices of $6.8,2.0,8.8,1.4,6.3,5.0$, and 1.8 fibreyears ( $\mathrm{f} / \mathrm{m}^{3} \times$ years).

\section{Standardised questionnaire}

Tables 3 and 4 present the crude prevalence of respiratory symptoms and diseases in the different categories of exposure. Mucosal irritation in general, dry nose, blocked nose, hoarseness, cough, dyspnoea, and exercise induced dyspnoea

Table 2 Ambient monitoring results for inhalable and respirable dust, and fibre concentrations

\begin{tabular}{|c|c|c|c|}
\hline & $\begin{array}{l}\text { Inhalable dust } \\
\left(\mathrm{mg} / \mathrm{m}^{3}\right)\end{array}$ & $\begin{array}{l}\text { Respirable dust } \\
\left(\mathrm{mg} / \mathrm{m}^{3}\right)\end{array}$ & Fibres $\left(f / \mathrm{m}^{3}\right)$ \\
\hline No. of measurements & 105 & 24 & 82 \\
\hline Mean (SD) & $10.3(15.1)$ & $0.22(0.28)$ & $415000(406000)$ \\
\hline Minimum & 0.2 & $<\mathrm{DL}$ & $<\mathrm{DL}$ \\
\hline Maximum & 96.1 & 1.02 & 1500000 \\
\hline $90 \%$ quartile & 20.4 & 0.68 & 1107000 \\
\hline
\end{tabular}


Table 3 Prevalence (\%) of respiratory symptoms with relation to cumulative dust exposure (in dustyears)

\begin{tabular}{lccrrr}
\hline & Controls & $\leqslant 25$ & $25-100$ & $>100$ & p value* \\
\hline Symptoms & & & & & \\
Mucosal irritation & 7 & 16.3 & 22.4 & 24.5 & $<0.001$ \\
Dry nose & 2.8 & 12.2 & 29.4 & 32.5 & $<0.001$ \\
Blocked nose & 1.4 & 0 & 23.1 & 29.8 & $<0.001$ \\
Sneezing attacks & 4.2 & 9.3 & 11.7 & 5.3 & 0.076 \\
Nose bleeding & 0 & 2 & 2.1 & 4.8 & 0.198 \\
Hoarseness & 0 & 14.3 & 16.8 & 17.2 & 0.046 \\
Cough & 0 & 2 & 3.5 & 4.6 & 0.001 \\
Phlegm & 0 & 0 & 3.5 & 6.6 & 0.006 \\
Dyspnoea & 9.7 & 9.3 & 12.3 & 19.9 & 0.021 \\
Exercise induced dyspnoea & & & & & \\
Diseases & 6.9 & 5.6 & 7.3 & 6.6 & 0.999 \\
Sinusitis & 5.6 & 0 & 0.7 & 3.1 & 0.552 \\
Laryngitis & 12.5 & 5.6 & 19.6 & 23.6 & 0.006 \\
Chronic bronchitis & 2.8 & 5.6 & 7.3 & 3.3 & 0.999 \\
Asthma & 13.9 & 13.0 & 16.7 & 11.2 & 0.647 \\
Pneumonia & 1.4 & 0 & 2.7 & 2.6 & 0.437 \\
Tuberculosis & 9.7 & 3.7 & 12.0 & 9.2 & 0.760 \\
Acute bronchitis & & & & & \\
\hline * Exact Cochran Armitage test. & & & &
\end{tabular}

were reported significantly more frequently by soft tissue workers compared with controls in relation to dust exposure. Moreover the prevalence of these symptoms increased with cumulative dust exposure. Chronic bronchitis was the only respiratory disease reported significantly more frequently compared with controls. Similar results were found for cumulative fibre exposure (in fibreyears). Additionally the symptom "sneezing attack" reached significance (table 4). As these crude analyses did not take the potentially confounding effect of other factors into account, we performed a multivariable logistic regression analysis incorporating these confounders.

Odds ratios with relation to cumulative dust exposure intensity after adjustment for factory, age, gender, and smoking habits were significantly raised for blocked nose $(\leqslant 25$ dustyears), mucosal irritation, dry nose, cough (>25 dustyears), hoarseness, phlegm, exercise induced dyspnoea, and sneezing attacks ( $>100$ dustyears). For these symptoms odds ratios increased with increasing cumulative exposure intensity (table 5). Cumulative dust exposure had no significant effects on the prevalence of respiratory diseases. Some odds ratios were below one. However, sinusitis, laryngitis, and chronic bronchitis showed increasing odds ratios with increasing cumulative dust exposure (table 5).

Odds ratios with relation to cumulative fibre exposure intensity after adjustment for factory, age, gender, and smoking habits were significantly raised for dry nose, blocked nose ( $\leqslant 3$ fibreyears), mucosal irritation, hoarseness, cough, dyspnoea, and exercise induced dyspnoea ( $>3$ fibreyears) (table $6)$. Odds ratios for respiratory diseases were below one in several cases without reaching significance (table 6).

The results of the logistic regression analysis for the differentiation between effects of intensity and duration of exposure are presented in table 7 for dust exposure and in table 8 for fibre exposure. For example, intensity and duration of exposure have an almost equal influence on the symptom "blocked nose". The calculated ORs rise with increasing exposure intensity from 6.4 to 10.8 and with increasing exposure duration from 6.4 to 12.5 . The highest OR was found in the category with highest exposure intensity and duration (18.8). Therefore a combined effect of both variables has to be taken into account. Similar results could be observed for other symptoms. For chronic bronchitis, the effect of intensity and

\begin{tabular}{|c|c|c|c|c|}
\hline & Controls & $\leqslant 3$ & $>3$ & p value* \\
\hline \multicolumn{5}{|l|}{ Symptoms } \\
\hline Mucosal irritation & 0 & 20.2 & 24.8 & $<0.001$ \\
\hline Dry nose & 7 & 32.1 & 25.4 & 0.048 \\
\hline Blocked nose & 2.8 & 25.3 & 23.6 & $<0.004$ \\
\hline Sneezing attacks & 1.4 & 1.1 & 6.7 & 0.013 \\
\hline Nose bleeding & 4.2 & 11.5 & 9.6 & 0.427 \\
\hline Hoarseness & 0 & 2.3 & 4.2 & 0.059 \\
\hline Cough & 0 & 15.7 & 17.6 & 0.001 \\
\hline Phlegm & 0 & 3.4 & 4.2 & 0.123 \\
\hline Dyspnoea & 0 & 1.1 & 7.9 & $<0.001$ \\
\hline Exercise induced dyspnoea & 9.7 & 11.5 & 19.2 & 0.028 \\
\hline \multicolumn{5}{|l|}{ Diseases } \\
\hline Sinusitis & 6.9 & 6.9 & 6.6 & 0.999 \\
\hline Laryngitis & 5.6 & 1.0 & 2.3 & 0.371 \\
\hline Chronic bronchitis & 12.5 & 14.7 & 24.3 & 0.012 \\
\hline Asthma & 2.8 & 5.3 & 5.4 & 0.533 \\
\hline Pneumonia & 13.9 & 16.4 & 10.8 & 0.328 \\
\hline Tuberculosis & 1.4 & 2.1 & 2.4 & 0.652 \\
\hline Acute bronchitis & 9.7 & 9.0 & 10.2 & 0.909 \\
\hline
\end{tabular}


Table 5 Results of the logistic regression analysis for respiratory symptoms and diseases with relation to cumulative exposure in dustyears, adjusted for factory, age, smoking habits, and gender

\begin{tabular}{|c|c|c|c|c|}
\hline & \multicolumn{4}{|c|}{ Cumulative exposure in dustyears $\left(\mathrm{mg} / \mathrm{m}^{3} \times\right.$ years) } \\
\hline & 0 & $\leqslant 25$ & $25-100$ & $>100$ \\
\hline \multicolumn{5}{|l|}{ Symptoms } \\
\hline Nose bleeding & 1 & $1.9(0.4$ to 10.6$)$ & $2.9(0.9$ to 13.3$)$ & 3.0 (0.9 to 14.0$)$ \\
\hline Mucosal irritation & - & 1 & 3.7 (1.6 to 9.1$)$ & 6.5 (2.8 to 17.2$)$ \\
\hline Dry nose & 1 & $1.9(0.5$ to 8.0$)$ & 6.5 (2.4 to 21.2$)$ & 8.9 (3.4 to 28.7$)$ \\
\hline Blocked nose & 1 & 5.9 (1.2 to 44.2$)$ & 11.5 (3.2 to 74.6$)$ & $18.2(5.2$ to 116.1$)$ \\
\hline Sneezing attacks & - & 1 & 4.1 (0.6 to 80.7 ) & 7.9 (1.0 to 170.7$)$ \\
\hline Hoarseness & - & 1 & $2.4(0.3$ to 52.1 & $11.3(1.4$ to 247.1$)$ \\
\hline Cough & - & 1 & 3.1 (1.3 to 8.2 ) & 3.5 (1.4 to 9.7$)$ \\
\hline Phlegm & - & 1 & $3.6(0.6$ to 71.0$)$ & $7.5(1.1$ to 154.2$)$ \\
\hline Dyspnoea & - & - & 1 & $3.1(0.9$ to 11.5$)$ \\
\hline Exercise induced dyspnoea & 1 & 1.7 (0.4 to 6.8$)$ & 2.5 (0.9 to 7.8$)$ & $2.6(1.0$ to 7.6$)$ \\
\hline \multicolumn{5}{|l|}{ Diseases } \\
\hline Sinusitis & 1 & $0.3(0.1$ to 1.5$)$ & 0.5 (0.2 to 2.0$)$ & 0.9 (0.3 to 3.7$)$ \\
\hline Laryngitis & - & 1 & $0.5(0.02$ to 5.0$)$ & $1.1(0.2$ to 6.6$)$ \\
\hline Chronic bronchitis & 1 & $0.2(0.1$ to 1.0$)$ & $1.1(0.4$ to 2.8$)$ & $1.5(0.6$ to 3.7$)$ \\
\hline Asthma & 1 & $1.5(0.2$ to 14.0$)$ & $3.0(0.6$ to 23.2$)$ & $1.8(0.3$ to 13.9$)$ \\
\hline Pneumonia & 1 & $1.1(0.3$ to 3.5$)$ & $1.3(0.5$ to 3.2$)$ & $0.6(0.2$ to 1.5$)$ \\
\hline Tuberculosis & - & 1 & 3.3 (0.5 to 69.7) & $3.4(0.4$ to 71.1$)$ \\
\hline Acute bronchitis & 1 & $0.3(0.03$ to 1.3$)$ & $1.2(0.4$ to 4.0$)$ & $1.0(0.4$ to 3.2$)$ \\
\hline
\end{tabular}

Results expressed as OR $(95 \% \mathrm{Cl})$. Cumulative exposure of less than 25 dustyears has been used as reference if there were no controls with symptoms or diseases.

Table 6 Results of the logistic regression analysis for respiratory symptoms and diseases with relation to cumulative exposure in fibreyears, adjusted for factory, age, smoking habits, and gender

\begin{tabular}{|c|c|c|c|}
\hline & \multicolumn{3}{|c|}{ Cumulative exposure in fibreyears $\left(\mathrm{f} / \mathrm{m}^{3} \times\right.$ years) } \\
\hline & 0 & $\leqslant 3$ & $>3$ \\
\hline \multicolumn{4}{|l|}{ Symptoms } \\
\hline Nose bleeding & 1 & $2.8(0.9$ to 12.5$)$ & $2.8(0.8$ to 13.3$)$ \\
\hline Mucosal irritation & - & 1 & 2.5 (1.3 to 4.9$)$ \\
\hline Dry nose & 1 & 6.2 (2.4 to 19.8$)$ & 9.3 (3.2 to 32.3 ) \\
\hline Blocked nose & 1 & 13.0 (3.7 to 83.3$)$ & $16.6(4.5$ to 108.9$)$ \\
\hline Sneezing attacks & 1 & 0.4 (0.03 to 9.7$)$ & 4.0 (0.5 to 84.9$)$ \\
\hline Hoarseness & - & 1 & 5.2 (1.1 to 28.1$)$ \\
\hline Cough & - & 1 & 2.5 (1.2 to 5.3$)$ \\
\hline Phlegm & - & 1 & $2.7(0.7$ to 12.0$)$ \\
\hline Dyspnoea & - & 1 & 7.9 (1.7 to 58.6$)$ \\
\hline Exercise induced dyspnoea & 1 & $1.9(0.7$ to 5.7$)$ & 3.7 (1.3 to 11.6$)$ \\
\hline \multicolumn{4}{|l|}{ Diseases } \\
\hline Sinusitis & 1 & $0.5(0.2$ to 1.9$)$ & $0.8(0.2$ to 3.3$)$ \\
\hline Laryngitis & 1 & $0.4(0.04$ to 3.0$)$ & $1.0(0.1$ to 9.1$)$ \\
\hline Chronic bronchitis & 1 & $0.8(0.3$ to 1.9$)$ & $1.9(0.8$ to 4.9$)$ \\
\hline Asthma & 1 & $1.6(0.4$ to 12.2$)$ & $3.2(0.6$ to 25.5$)$ \\
\hline Pneumonia & 1 & $1.3(0.6$ to 3.0$)$ & $0.5(0.2$ to 1.3$)$ \\
\hline Tuberculosis & 1 & $1.5(0.2$ to 15.7$)$ & $2.3(0.2$ to 25.5$)$ \\
\hline Acute bronchitis & 1 & 0.8 (0.3 to 2.4$)$ & $1.3(0.4$ to 4.3$)$ \\
\hline
\end{tabular}

duration of exposure is not statistically significant, but the highest odds ratio (1.57) in the subgroup with longest and highest exposure suggests some deleterious potential (table 7).

Similar results were found with relation to fibre exposure. The effect of duration of fibre exposure on the symptom "blocked nose" is more than the effect of exposure intensity (table 8).

\section{DISCUSSION}

Animal experiments with cellulose fibre tissue suggest that cellulose fibres have a long biopersistency, at least in rat lung, and can cause slight interstitial fibrosis as well as alveolar cell type hyperplasia. ${ }^{1-4}$ In 1988 and 1989, reports of a higher prevalence of respiratory symptoms and diseases in soft tissue workers exposed to cellulose were published..$^{5-7}$ Ericsson et al reported a dose dependent increased prevalence of upper respiratory tract symptoms, comparable to the results of our study. ${ }^{5}$ Jarvholm et al and Thorén et al also described a higher prevalence of lower respiratory tract symptoms. ${ }^{67}$ It has been a matter of concern, whether fibre shape of cellulose containing dusts might be responsible for health complaints and respiratory diseases. Therefore inhalable dust and fibre dust concentrations were simultaneously determined in our study. Results of the ambient monitoring revealed very high dust exposures for the inhalable dust fraction, whereas the respirable fraction was low (table 2). Because of these results, the high prevalence of upper respiratory symptoms is not unexpected. 
Table 7 Odds ratios $(95 \% \mathrm{Cl})$ of respiratory symptoms in relation to dust exposure intensity and years of exposure ladjusted for factory, age, gender, and smoking habits)

\begin{tabular}{|c|c|c|}
\hline \multirow{2}{*}{$\begin{array}{l}\text { Dust exposure } \\
\left(\mathrm{mg} / \mathrm{m}^{3}\right)\end{array}$} & \multicolumn{2}{|l|}{ Years of exposure } \\
\hline & 0 to $\leqslant 15$ & $>15$ \\
\hline \multicolumn{3}{|l|}{ Dry nose } \\
\hline$>5$ & 6.1 (2.2 to 20.0$)$ & 8.6 (3.2 to 27.8 ) \\
\hline 0 to $\leqslant 5$ & $3.1(0.8$ to 12.5$)$ & 5.7 (1.5 to 23.2 ) \\
\hline \multicolumn{3}{|l|}{ Blocked nose } \\
\hline$>5$ & 10.8 (2.9 to 70.5$)$ & 18.8 \\
\hline 0 to $\leqslant 5$ & 6.4 (1.2 to 49.7$)$ & $12.5(2.9$ to 88.6$)$ \\
\hline \multicolumn{3}{|l|}{ Mucosal irritation } \\
\hline$>5$ & 3.3 (1.4 to 8.7$)$ & 6.6 (2.7 to 18.4$)$ \\
\hline 0 to $\leqslant 5$ & 1 (reference) & $3.7(1.1$ to 8.7$)$ \\
\hline \multicolumn{3}{|l|}{ Dry cough } \\
\hline$>5$ & $2.1(0.9$ to 5.5$)$ & 3.3 (1.4 to 8.8$)$ \\
\hline 0 to $\leqslant 5$ & 1 (reference) & 2.5 (0.7 to 8.7$)$ \\
\hline \multicolumn{3}{|l|}{ Nose bleeding } \\
\hline$>5$ & 3.6 (1.0 to 16.7$)$ & 2.5 (0.7 to 11.5$)$ \\
\hline 0 to $\leqslant 5$ & $1.6(0.3$ to 9.6$)$ & $2.8(0.6$ to 15.6$)$ \\
\hline \multicolumn{3}{|l|}{ Sinusitis } \\
\hline$>5$ & 0.3 (0.1 to 1.4$)$ & $1.1(0.3$ to 4.3$)$ \\
\hline 0 to $\leqslant 5$ & $0.3(0.04$ to 1.4$)$ & $0.9(0.1$ to 5.1$)$ \\
\hline \multicolumn{3}{|l|}{ Chronic bronchitis } \\
\hline$>5$ & $0.8(0.3$ to 2.1$)$ & $1.6(0.7$ to 4.0$)$ \\
\hline 0 to $\leqslant 5$ & $0.5(0.1$ to 1.7$)$ & $1.3(0.4$ to 4.2$)$ \\
\hline \multicolumn{3}{|l|}{ Asthma } \\
\hline$>5$ & $2.5(0.5$ to 19.9$)$ & $1.5(0.3$ to 12.1$)$ \\
\hline 0 to $\leqslant 5$ & $2.0(0.3$ to 19.1$)$ & $4.0(0.5$ to 40.4$)$ \\
\hline \multicolumn{3}{|l|}{ Pneumonia } \\
\hline$>5$ & $1.0(0.4$ to 2.8$)$ & $0.6(0.2$ to 1.5$)$ \\
\hline 0 to $\leqslant 5$ & $0.8(0.2$ to 2.8$)$ & $1.6(0.6$ to 4.9$)$ \\
\hline \multicolumn{3}{|l|}{ Acute bronchitis } \\
\hline$>5$ & $0.9(0.3$ to 2.2$)$ & $1.0(0.3$ to 3.2$)$ \\
\hline 0 to $\leqslant 5$ & 0.5 (0.1 to 2.2$)$ & $1.5(0.3$ to 6.8$)$ \\
\hline
\end{tabular}

Because of the high dust exposure and the cross sectional study design, a healthy worker effect has to be considered. Workers with manifest respiratory diseases are not able to work under dusty conditions at paper machines or combiners. This effect is reflected in the odds ratios for respiratory diseases below one (tables 5 and 6 ). The healthy worker effect might lead to a considerable underestimation of the effects described.

For symptoms of the upper airways, clear dose-response relations could be found with relation to cumulative exposure indices based on a high number of dust measurements. As expected, because of the distribution of inhalable and respirable dust fraction, symptoms of the lower respiratory tract have a weaker association with exposure after adjustment for confounders (for example, cough, phlegm, dyspnoea, and exercise induced dyspnoea). These results correspond with those of Zuskin et al from a paper recycling factory. ${ }^{13}$ The findings of a mortality study by Thorén et al, who reported an increased risk of bronchial asthma and chronic obstructive pulmonary disease associated with employment at paper mills, could not be confirmed. ${ }^{7}$ However, the study design was different to that of our study. Rylander et al did not report differences with respect to chronic bronchitis between workers and controls in their cross sectional study. ${ }^{14}$

The results of our study do not support the hypothesis that cellulose fibre exposure has a separate or specific effect on symptom or disease prevalence of the respiratory tract. However, a clear separation of specific effects is not possible because of methodological problems (different units). The interpretation has to take into account the fact that fibres are part of the total dust amount. However, the risk estimates with relation to cumulative dust and fibreyears reveal similar results (tables 5 and 6 ).
Table 8 Odds ratios $(95 \% \mathrm{Cl})$ of respiratory symptoms with relation to fibre exposure intensity and years of exposure (adjusted for factory, age, gender, and smoking habits)

\begin{tabular}{|c|c|c|}
\hline \multirow{2}{*}{$\begin{array}{l}\text { Fibre exposure } \\
\left(\mathrm{mg} / \mathrm{m}^{3}\right)\end{array}$} & \multicolumn{2}{|l|}{ Years of exposure } \\
\hline & 0 to $\leqslant 15$ & $>15$ \\
\hline \multicolumn{3}{|l|}{ Dry nose } \\
\hline$>0.3$ & 9.2 (1.8 to 48.5$)$ & ${ }^{22.2}$ (4.7 to 104.5$)$ \\
\hline 0 to $\leqslant 0.3$ & 5.6 (1.9 to 16.8 ) & $6.6(2.2$ to 19.4$)$ \\
\hline \multicolumn{3}{|l|}{ Blocked nose } \\
\hline$>0.3$ & 7.2 (1.3 to 57.7$)$ & ${ }^{17.5}(4.1$ to 125.4$)$ \\
\hline 0 to $\leqslant 0.3$ & 11.2 (2.9 to 74.7 ) & ${ }^{17.4}(4.8$ to 112.9$)$ \\
\hline \multicolumn{3}{|l|}{ Mucosal irritation } \\
\hline$>0.3$ & $2.8(0.8$ to 10.6$)$ & 6.5 (2.2 to 22.2 ) \\
\hline 0 to $\leqslant 0.3$ & 1 (reference) & $2.7(1.3$ to 5.8$)$ \\
\hline \multicolumn{3}{|l|}{ Dry cough } \\
\hline$>0.3$ & $2.4(0.6$ to 10.8$)$ & $3.1(1.3$ to 8.0$)$ \\
\hline 0 to $\leqslant 0.3$ & 1 (reference) & $2.0(0.9$ to 4.4$)$ \\
\hline \multicolumn{3}{|l|}{ Nose bleeding } \\
\hline$>0.3$ & 1.5 (0.3 to 9.9$)$ & 2.8 (0.7 to 15.2$)$ \\
\hline 0 to $\leqslant 0.3$ & 4.1 (1.3 to 20.1$)$ & $2.2(0.6$ to 10.6$)$ \\
\hline \multicolumn{3}{|c|}{ Chronic bronchitis } \\
\hline$>0.3$ & $0.9(0.3$ to 1.7$)$ & $1.1(0.4$ to 3.5$)$ \\
\hline 0 to $\leqslant 0.3$ & $0.6(0.2$ to 1.7$)$ & $1.8(0.8$ to 4.7$)$ \\
\hline \multicolumn{3}{|l|}{ Asthma } \\
\hline$>0.3$ & 6.4 (0.6 to 112.3 ) & $0.9(0.03$ to 15.4$)$ \\
\hline 0 to $\leqslant 0.3$ & $1.8(0.3$ to 14.3$)$ & $2.6(0.5$ to 20.2$)$ \\
\hline \multicolumn{3}{|l|}{ Pneumonia } \\
\hline$>0.3$ & 0.8 (0.2 to 2.8 ) & 0.5 (0.2 to 1.8 ) \\
\hline 0 to $\leqslant 0.3$ & $1.1(0.4$ to 3.1$)$ & 0.9 (0.4 to 2.3$)$ \\
\hline \multicolumn{3}{|l|}{ Acute bronchitis } \\
\hline$>0.3$ & $1.0(0.2$ to 7.0$)$ & $1.0(0.2$ to 6.0$)$ \\
\hline 0 to $\leqslant 0.3$ & $0.7(0.2$ to 2.5$)$ & 1.1 (0.4 to 3.7$)$ \\
\hline
\end{tabular}

We differentiated, for the first time, between effects of exposure intensity and exposure duration in workers from the soft tissue producing industry. Because of the limited sample size, our findings are preliminary and should be interpreted with caution. The results suggest that exposure intensity may be responsible for the majority of the detected effects regarding respiratory symptoms. However, duration of exposure contributed to the effects in almost all symptoms to a smaller degree. This could provide some evidence for a link to possible chronic effects. After adjustment for smoking habits, chronic bronchitis was no longer significantly associated with dust or fibre exposure. However, the highest odds ratio (1.57) in the subgroup with longest and highest exposure suggests some deleterious potential. Taking the healthy worker effect into account, this finding should be of interest for future studies on the relation between lower respiratory tract diseases and dust exposure.

In this context it should be considered whether dust and fibre concentrations in our study are surrogate markers for non-detected exposures at the workplaces. It is well known that in the soft tissue industry a complex exposure situation exists. ${ }^{15}{ }^{16}$ Moreover a high prevalence of respiratory symptoms has been reported from other worksites with organic dust exposure outside the soft tissue industry, for example, among biowaste collectors, compost workers, and farmers. ${ }^{17}{ }^{18}$ Respiratory symptoms could be non-specifically related to the very high dust concentrations, no matter what kind of dust exposure takes place. Searching for the aetiological agent, Rylander et al found that airborne endotoxin and $\beta(1,3)$ glucan exposure were responsible for the increased prevalence of respiratory symptoms in a group of 83 workers employed in bark cleaning units, recycled paper storage and processing in the paper industry. ${ }^{14}$ This exposure is not comparable with soft 
tissue production. Recycled paper and recycled paper dust and fibres have different properties (for example, diminished fibre length) than soft tissue paper dust. Moreover dust concentrations are higher in soft tissue production. Because of the results of the markers of inflammation determined by Rylander et al, airway inflammation may be responsible for the increased symptom prevalence. ${ }^{14}$ However, the responsible agent still remains unclear. Douwes et al, in their study of saw mills, reported that dust levels were only weakly correlated with endotoxin and $\beta(1,3)$-glucan concentrations. ${ }^{19}$ It is therefore questionable whether the dust concentrations detected in our study can serve as a surrogate for endotoxin exposures. It is concluded that most of the results suggest that the effects detected are a result of the high dust concentration, regardless of its fibre content.

A reduction of dust exposure should therefore be recommended in the soft tissue paper producing industry. Further investigations to identify the aetiological agent or agents within the dust fraction are recommended.

\section{Authors' affiliations}

T Kraus, Institute and Outpatient Clinic for Occupational Medicine, University Hospital, Aachen University of Technology, Germany A Pfahlberg, O Gefeller, Department of Medical Informatics, Biometry and Epidemiology

H J Raithel, Institute and Outpatient Clinic for Occupational, Social and Environmental Medicine, University of Erlangen-Nuremberg, Germany

\section{REFERENCES}

1 Muhle H. Bellmann B. Untersuchungen der Beständigkeit von Zellulosefasern in der Rattenlunge. Hannover: Fraunhofer Institut für Toxikologie und Aerosolforschung, 1995.

2 Milton DK, Godleski JL, Feldman HA, et al. Toxicity of intratracheally instilled cotton dust, cellulose, and endotoxin. Am Rev Respir J Dis 1990;142:184-92.
3 Tatrai E, Ungvry G. The aetiology of experimental fibrosing alveobronchitis induced by rats by paprika dust. $\mathrm{Br} J$ Ind Med 1992;49:494-8

4 Davis JMG. The need for standardising testing procedures for all products capable of liberating respirable fibres: the example of materials based on cellulose. Br J Ind Med 1993;50:187-90.

5 Ericsson J, Järvholm B, Norin F. Respiratory symptoms and lung function following in workers exposed to soft paper tissue dust. Int Arch Occup Environ Health 1988;60:341-5.

6 Jarvholm B, Thorén K, Brolin I, et al. Lung function in workers exposed to soft paper dust. Am J Ind Med 1988;14:457-64.

7 Thorén K, Sällsten G, Bake B, et al. Lung function and respiratory symptoms among workers in a soft paper mill. Int Arch Occup Environ Health 1989:61:467-71.

8 Thorén K, Järvholm B, Sällsten G, et al. Respiratory symptoms and asthma among workers exposed to paper dust: a cohort study. Am J Ind Med 1994;26:489-96

9 TRGS 402. Technical guidance note for hazardous substances. Detection and measurement of hazardous substances at the workplace. Bundesarbeitsblatt 1977;1 1:27-38

10 British Medical Research Council, Committee on the Aetiology of Chronic Bronchitis. Standardised questionnaire on respiratory symptoms. London: British Medical Council, 1986

11 Armitage P. Tests for linear trends in proportions and frequencies. Biometrics 1955; 11:375-86.

12 Venzon DJ, Moolgavkar SH. A method for computing profile-likelihood based confidence intervals. Applied Statistics 1988;37:87-94.

13 Zuskin E, Mustaibegovic J, Schachter EN, et al. Respiratory function and immunological status in paper-recycling workers. J Occup Environ Med 1998;40:986-93.

14 Rylander R, Thorn J, Attefors R. Airways inflammation among workers in a paper industry. Eur Respir J 1999;13:1151-7.

15 Kauppinen T, Teschke K, Savela A, et al. International data base of exposure measurements in the pulp, paper and paper product industries. Int Arch Occup Environ Health 1997;70: 1 19-27.

16 Ahrens W, Jöckel KH. Expositionen gegenüber Gefahrstoffen in der Papier- und Zellstoffindustrie. Zbl Arbeitsmed 1997;47:390-401.

17 Bünger J, Antlauf-Lammers M, Schulz T, et al. Health complaints and immunological markers of exposure to bioaerosols among biowaste collectors and compost workers. Occup Environ Med 2000;57:458-64

18 Ahman M, Holmström M, Kolmodin-Hedman B, et al. Nasal symptoms and pathophysiology in farmers. Int Arch Occup Environ Health $2001 ; 74: 279-84$

19 Douwes J, McLean D, van der Maarl E, et al. Worker exposures to airborne dust, endotoxin and $\beta(1,3)$-glucan in two new zealand sawmills. Am J Ind Med 2000;38:426-30.

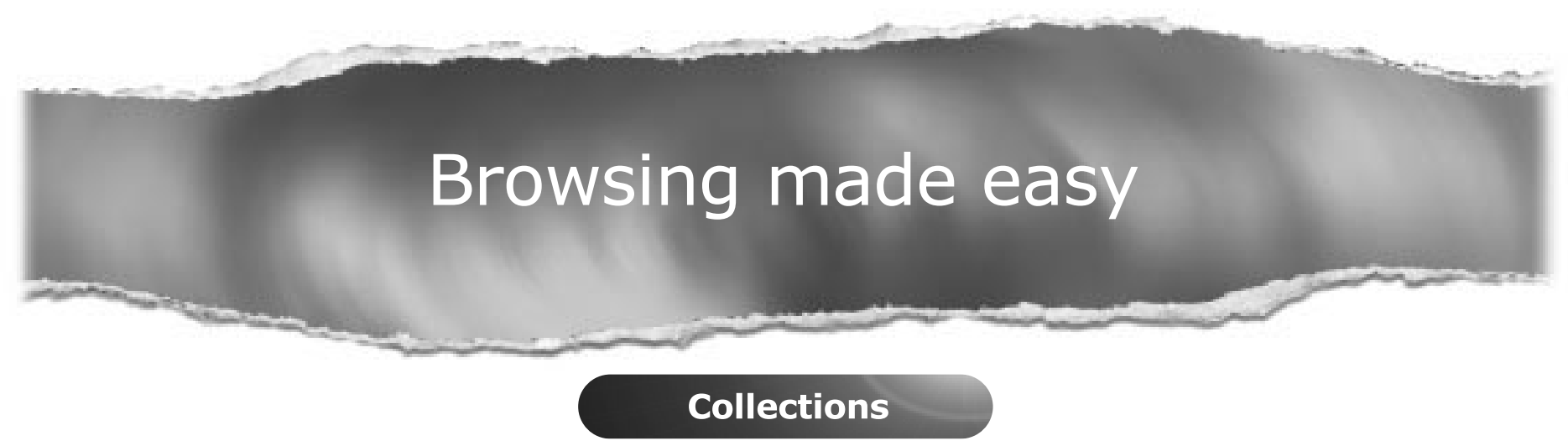

With a single click Collections allows you to find all articles that have been published in your chosen subject. Select from over 200 clinical and non-clinical topic collections and/or cross search other specialist journals, the BMJ and Cochrane Reviews 